2. Marked changes were seen only in the adrenal glands, where the size and lipid content of the zona glomerulosa were increased in rats totally deprived of pantothenic acid and in those having small curative doses. Increased lipid was found also in the zona fasciculata of the animals recovering from deprivation. These changes are contrasted with those seen in the adrenal glands of pyridoxine-deficient rats.

The authors wish to express their sincere thanks to Mrs A. D. Blunt and Mrs E. Cheesman who helped in the preparation of the sections, and to $\mathrm{Mr}$ G. Willoughby who took the photographs.

\title{
REFERENCES
}

Ashburn, H., Daft, F. S. \& Faulkner, R. R. (1947). Blood, 2, 45 I.

Blunt, A. D., Cheesman, E. M. \& Copping, A. M. (1957). Brit. F. Nutr. I1, 62.

Combridge, C. D. (1956). Brit. F. Nutr. ro, 347.

Deane, H. W. \& McKibbin, J. M. (1946). Endocrinology, 38, 385 .

Morgan, A. F. (1951). Vitam. \&ั Horm. 9, 161.

Winters, R. W., Schultz, R. B. \& Krehl, W. A. (1952a). Endocrinology, 50, 377.

Winters, R. W., Schultz, R. B. \& Krehl, W. A. (1952b). Endocrinology, 50, $3^{88}$.

\section{Further studies on antibiotic and copper supplements for fattening pigs*}

\author{
By R. S. BARBER, R. BRAUDE, K. G. MITCHELL \\ AND J. A. F. ROOK \\ National Institute for Research in Dairying, Shinfield, near Reading \\ AND J. G. ROWELL \\ Agricultural Research Council Statistics Group, \\ School of Agriculture, Cambridge \\ (Received 24 September 1956)
}

Barber, Braude, Mitchell \& Cassidy (1955) and Bowler, Braude, Campbell, CraddockTurnbull, Fieldsend, Griffiths, Lucas, Mitchell, Nickalls \& Taylor (1955) reported that the growth rate of pigs was improved when their normal fattening ration was supplemented with a high-copper mineral mixture. Later, Barber, Braude \& Mitchell (1955) showed that the addition of $0.1 \%$ copper sulphate (supplying 250 p.p.m. copper) to a fattening-pig diet was as effective as chlorotetracycline (aureomycin) in increasing growth rate. The findings suggested that the faster growth of the copper-supplemented pigs was due to improved food utilization rather than increased food consumption.

Three further experiments are reported here, in which the effects of copper and antibiotic supplements on growth rate, food conversion, food consumption, carcass

* Read in part before The Nutrition Society on 26 May I956 (Barber, Braude, Mitchell, Rook \& Rowell, 1956). 
quality and the general well-being of the pig were investigated. To study the distribution of copper in the pig's body, the weight and copper content of various tissues were measured. The level of copper in the tissues is an indication of whether the carcass is suitable for human consumption. To study the question of toxicity in the pig itself, a further experiment was carried out in which high levels of copper were included in the diet. A preliminary trial was also carried out on the value of Vigofac* as a supplement for fattening pigs.

\section{EXPERIMENTAL}

In all experiments pigs from the Shinfield, virus pneumonia-free, Large White herd were used, and individual feeding was employed. The basal meal used was of the same composition as that used previously (Barber, Braude \& Mitchell, 1955).

\section{Experiment I}

The effects of the following five dietary supplements were studied: (I) none (control), (2) Vigofac (1o lb./ton), (3) oxytetracycline (10 g/ton), (4) Vigofac (1o lb./ ton) with oxytetracycline $\left(6 \mathrm{~g} /\right.$ ton), and (5) $\mathrm{CuSO}_{4} \cdot{ }_{5} \mathrm{H}_{2} \mathrm{O}(0 \cdot 1 \%)$. Ten $\mathrm{lb}$. of Vigofac contain $4 \mathrm{~g}$ oxytetracycline so that supplements 3 and 4 contained the same quantity of oxytetracycline. There were twelve pigs on each treatment and there was no direct contact between pigs on different treatments.

The experiment was carried out partly in a Danish-type piggery and partly in an experimental piggery in which the pigs were housed in individual pens. That part of the experiment in the Danish-type piggery was carried out in two replicates; for the first of these, thirty weaners were available but, since they came from seven different litters, it was not possible to balance litter origin. The pigs were therefore allocated to the treatments so as to form a randomized block design, the blocks being composed of pigs of very similar initial weight; there were four males and two females on each treatment and the pigs were 9-I I weeks old when the experiment began. In the second replicate twenty pigs were available, $8 \frac{1}{2}-10 \frac{1}{2}$ weeks old. The design was again a randomized block, but this time blocks corresponded to litters. In both replicates, treatments were allocated to pens at random. In that part of the experiment carried out in the experimental piggery, there were five pigs from each of two litters and these were allocated to the ten individual pens at random.

All pigs were given twice daily as much meal as they would consume within $3 \circ \mathrm{min}$, up to a maximum of $7 \mathrm{lb}$. /day, water at the rate of $3 \mathrm{lb}$. to every $\mathrm{lb}$. meal being added immediately before feeding. The pigs were weighed once weekly throughout the experiment and were sent to slaughter individually when their live weight exceeded $203 \mathrm{lb}$.

Immediately after slaughter the liver, kidneys and spleen and samples of back fat and of the fillet (psoas muscle) were taken from six pairs of litter-mate control and copper-supplemented pigs and stored at $-20^{\circ}$. The copper content of these tissues and

\footnotetext{
* Vigofac is a proprietary fermentation product for which its manufacturers (Pfizer Ltd) claim that it contains a growth-promoting factor of unknown identity.
} 
organs was determined by the method of Andrus (1955). For all samples except fat, $0.5-5 \mathrm{~g}$ of fresh material (depending on the copper content) were taken and wetashed; for fat, up to $20 \mathrm{~g}$ of wet tissue were dry-ashed and the ash was dissolved in dilute sulphuric acid.

\section{Experiment 2}

The effects of the following three supplements were studied: (I) none, (2) chlorotetracycline (at approximately $20 \mathrm{~g} /$ ton) ${ }^{*}$ and $(3) \mathrm{CuSO}_{4} \cdot{ }_{5} \mathrm{H}_{2} \mathrm{O}(0 \cdot 1 \%)$. The experiment was designed as a randomized block, blocks corresponding to litters. There were four males and two females on each treatment and the pigs were $9 \frac{1}{2}-1$ r weeks old when the experiment began. Treatments were allocated at random to pens in the Danishtype piggery, there being no direct communication between the pigs on the different treatments. The feeding routine was the same as described for Exp. I. The pigs were weighed once weekly.

After slaughter the small intestine, from the pylorus to the ileo-caecal junction, was removed from all pigs and was weighed and its length measured as described by Braude, Coates, Davies, Harrison \& Mitchell (1955). The liver, kidneys and spleen were also removed, cleaned of any extraneous tissue and weighed.

\section{Experiment 3}

The effects of a diet with a high copper content were studied in the following two treatments:

(I) A diet supplemented with $\mathrm{I} \cdot 0 \% \mathrm{CuSO}_{4} \cdot 5 \mathrm{H}_{2} \mathrm{O}$ for I 9 days, followed for 10 days by an unsupplemented diet, and then by a diet supplemented with $0.1 \% \mathrm{CuSO}_{4} \cdot 5 \mathrm{H}_{2} \mathrm{O}$ for 21 days.

(2) A diet supplemented with $0.5 \% \mathrm{CuSO}_{4} \cdot 5 \mathrm{H}_{2} \mathrm{O}$ for 36 days, followed by a diet supplemented with $0.1 \% \mathrm{CuSO}_{4} \cdot 5 \mathrm{H}_{2} \mathrm{O}$ for $\mathrm{I}_{4}$ days.

Four pairs of 10- to I I-week-old litter-mates were selected and penned individually in the experimental piggery. The meal was fed dry and ad lib., unrestricted water being available in a separate trough. The amount of food consumed by each pig was recorded daily and the animals were weighed once weekly.

\section{Biometrical methods}

In the analysis of the results of Exps. $I$ and 2 for the effect of the various diets on growth rate and food conversion, variations in initial and final weight have been allowed for; the corrected rate of food consumption was found by multiplying together the corrected growth rate and the corrected food conversion. Since pigs on different treatments were in different pens, variations between treatments should strictly be compared with variations between pens. In Exp. I, a between-pen estimate of variance was obtained by pooling the replicate $\times$ treatment interaction of the part carried out in the Danish-type piggery and the litter $\times$ treatment interaction of the part carried out in

\footnotetext{
* Given as Aurofac 2 A (Lederle Laboratories Inc.).
} 
the experimental piggery. This estimate was found to be less than the within-pen estimate of variance as obtained from the block $\times$ treatment interactions; the betweenpen estimate and the within-pen estimate were therefore pooled, and from this estimate the standard errors of the treatment means were calculated. In Exp. 2 no estimate of between-pen error was available and it was necessary to compare variations between the treatment means with a within-pen error. Although this was a valid test of significance, it tests the effect of treatment alone only if the pens had no effect on the three measures concerned; the results of Exp. I suggested that it was so.

The effect of diets supplemented by copper sulphate on the copper content of various tissues was tested by means of paired-sample $t$ tests, pairs corresponding to litter-mates. For liver, a logarithmic transformation was used, since the smaller values for the control diet were less variable than the values in the treated group.

In the analysis of the effect of the diets in Exp. 2 on some visceral measurements, the relation between these measurements and dead weight was considered. Regression analyses were carried out on the residuals of the randomized block analyses; variations in dead weight were small, however, and none of the regressions was significant, so that no corrections were made. The visceral measurements were analysed as a randomized block. Treatment effects in the analysis discussed in this and the preceding paragraph were confounded with pen effects.

No statistical analysis was carried out on the results of Exp. 3 .

\section{RESULTS \\ Experiments I and 2}

Growth rate, food conversion and rate of food consumption. The treatment means for Exps. $I$ and 2 are given in Tables $I$ and 2 . Vigofac did not significantly affect growth rate, food conversion or rate of food consumption, and none of these measures differed significantly between treatments 3 and 4 (oxytetracycline and Vigofac with oxytetracycline); this finding suggests that if Vigofac does have a beneficial effect it is due to its oxytetracycline content. Oxytetracycline and chlorotetracycline significantly increased growth rate and rate of food consumption; chlorotetracycline also improved food conversion. In both experiments the effect of copper sulphate on growth rate and rate of food consumption was highly significant. Although the mean figures show that copper sulphate improved food conversion in both experiments, the improvement was significant in neither. Combining the results for food conversion in the two experiments gave means of 3.35 and $3.22 \mathrm{lb}$. food consumed/lb. live-weight gain for the control and copper sulphate-supplemented diets respectively, with a standard error of 0.043 , the improvement of $3.9 \%$ being very nearly significant at the $5 \%$ level.

Commercial grading. The results are given in Table 3. The overall grading results were satisfactory, fifty-nine out of the seventy-seven carcasses from the two experiments $(76.6 \%)$ grading $A$. There was a reduction in both experiments in triple- $A$ carcasses from the pigs given copper but this reduction was not significant. 
Table I. Exp. I. Effect of diets supplemented with Vigofac $\dagger$, oxytetracycline or copper sulphate on growth rate, food conversion, live-weight gain, rate of food consumption and total food consumption of pigs

\begin{tabular}{|c|c|c|c|c|}
\hline Dietary supplement & $\begin{array}{l}\text { Growth rate } \\
\text { (lb. live-weight } \\
\text { gain/day) }\end{array}$ & $\begin{array}{l}\text { Food conversion } \\
\text { (lb. food } \\
\text { consumed/lb. } \\
\text { live-weight gain) }\end{array}$ & $\begin{array}{l}\text { Rate of food } \\
\text { consumption } \\
\text { (lb./day) }\end{array}$ & $\begin{array}{l}\text { Total food con- } \\
\text { sumption/pig } \\
\text { (lb.) }\end{array}$ \\
\hline None & I. 49 & $3 \cdot 32$ & $4 \cdot 92$ & $52 \mathrm{I}$ \\
\hline Vigofac (Io lb./ton) & $1 \cdot 55$ & $3 \cdot 28$ & $5 \cdot 05$ & 515 \\
\hline Oxytetracycline ( $\mathrm{r} 0 \mathrm{~g} /$ ton) & $I \cdot 58 * *$ & 3.28 & $5 \cdot 15 *$ & $5 \mathrm{I}_{4}$ \\
\hline $\begin{array}{l}\text { Vigofac (ro lb./ton) + oxy- } \\
\text { tetracycline }(6 \mathrm{~g} / \text { ton })\end{array}$ & $\mathrm{x} \cdot 6 \mathrm{r} * * *$ & $3 \cdot 28$ & $5 \cdot 28^{* * * *}$ & 515 \\
\hline $\begin{array}{l}\mathrm{CuSO}_{4} \cdot 5 \mathrm{H}_{2} \mathrm{O}(0 \cdot 1 \%) \\
\text { Standard error of the means }\end{array}$ & $\begin{array}{l}\mathrm{I} \cdot 65^{* * * *} \\
0.030\end{array}$ & $\begin{array}{l}3.21 \\
0.056\end{array}$ & $\begin{array}{l}5 \cdot 29^{* * * *} \\
0.060\end{array}$ & $\begin{array}{r}508 \\
9 \cdot 0\end{array}$ \\
\hline
\end{tabular}

The figures have been corrected for variations in initial and slaughter weights. The mean initial weight for the whole experiment was $47 \% 7 \mathrm{lb}$. and the pigs were slaughtered at about $210 \mathrm{lb}$. live weight. There were twelve pigs on each treatment.

Levels of significance for differences between treatment and control means are as follows: $*=0.05>$ $P>0.01 ; * *=0.01>P>0.001 ; * * *=P<0.001$.

$\dagger$ A fermentation product produced by Pfizer Ltd, which contains $4 \mathrm{~g}$ oxytetracycline/ro lb.

Table 2. Exp. 2. Effect of diets supplemented with chlorotetracycline (aureomycin) or copper sulphate on growth rate, food conversion, rate of food consumption and total food consumption of pigs

(Values based on the period of growth from 45 to $205 \mathrm{lb}$., six pigs on each treatment)

\begin{tabular}{|c|c|c|c|c|}
\hline etary supplement & $\begin{array}{l}\text { Growth rate } \\
\text { (lb. live-weight } \\
\text { gain/day) }\end{array}$ & $\begin{array}{l}\text { Food conversion } \\
\text { (lb. food } \\
\text { consumed/lb. } \\
\text { live-weight gain) }\end{array}$ & $\begin{array}{l}\text { Rate of food } \\
\text { consumption } \\
\text { (lb./day) }\end{array}$ & $\begin{array}{l}\text { Total food con- } \\
\text { sumption/pig } \\
\text { (lb.) }\end{array}$ \\
\hline $\begin{array}{l}2 \mathrm{~A}+(5 \mathrm{lb} . / 2000 \mathrm{lb} .) \\
5 \mathrm{H}_{2} \mathrm{O}(0 \cdot 1 \%) \\
\text { lard error of the means }\end{array}$ & $\begin{array}{l}I \cdot 42 \\
I \cdot 65^{* * *} \\
I \cdot 6 \mathrm{I} * * \\
0.029\end{array}$ & $\begin{array}{l}3.40 \\
3 \cdot 18^{*} \\
3.24 \\
0.054\end{array}$ & $\begin{array}{l}4.82 \\
5.24 * * \\
5.22 * * \\
0.088\end{array}$ & $\begin{array}{l}540 \\
505 \\
514 \\
9 \cdot 0\end{array}$ \\
\hline
\end{tabular}

Levels of significance of the effects of chlorotetracycline and $\mathrm{CuSO}_{4} \cdot 5 \mathrm{H}_{2} \mathrm{O}$ compared with the control are shown as in Table $\mathrm{I}$.

† Lederle Laboratories Inc., containing $3^{\cdot 6} \mathrm{~g}$ chlorotetracycline/ $\mathrm{lb}$.

Table 3. Results of commercial grading for carcasses of pigs in Exps. I and 2

\begin{tabular}{|c|c|c|c|c|c|c|}
\hline \multirow{2}{*}{$\begin{array}{c}\text { Exp. } \\
\text { no. }\end{array}$} & \multirow{2}{*}{$\begin{array}{l}\text { No. of } \\
\text { pigs }\end{array}$} & \multirow[b]{2}{*}{ Dietary supplement } & \multicolumn{4}{|c|}{ No. of carcasses graded: } \\
\hline & & & $A^{*}$ & B & $\mathrm{C}$ & Triple A \\
\hline \multirow[t]{5}{*}{$\mathbf{I}$} & 12 & None & 8 & 4 & $\circ$ & 5 \\
\hline & 12 & Vigofac & 9 & 3 & $\circ$ & 5 \\
\hline & 12 & Oxytetracycline & Io & 2 & 0 & 5 \\
\hline & 12 & Vigofac + oxytetracycline & 9 & 3 & $\circ$ & 2 \\
\hline & I I & $\mathrm{CuSO}_{4} \cdot 5 \mathrm{H}_{2} \mathrm{O}$ & 7 & 3 & $\mathbf{I}$ & 2 \\
\hline \multirow[t]{3}{*}{2} & 6 & None & 5 & $\mathbf{I}$ & 0 & 5 \\
\hline & 6 & Aurofac $2 \mathrm{~A}$ & 5 & $\mathbf{I}$ & $\circ$ & 4 \\
\hline & 6 & $\mathrm{CuSO}_{4} \cdot 5 \mathrm{H}_{2} \mathrm{O}$ & 6 & ○ & 0 & 3 \\
\hline
\end{tabular}


Copper content of tissues. The mean copper contents for various tissues for the control diet and the diet supplemented with copper sulphate are given in Table 4. The copper content of liver in the treated pigs showed wide variation with a range of $25 \cdot \mathrm{I}-3 \mathrm{I} 5.2 \mathrm{mg} / \mathrm{kg}$ wet material. The mean was about eight times that of the controls, a difference that was highly significant. Smaller, but significant, increases in the copper content of the muscle and kidney were also observed.

Table 4. Exp. I. Effect of a diet supplemented with $0.1 \%$ copper sulphate on the copper content of various tissues of pigs

(Mean values with their standard errors for groups of six pigs)

\begin{tabular}{lccl} 
& \multicolumn{3}{c}{$\begin{array}{c}\text { Copper content } \\
(\mathrm{mg} / \mathrm{kg} \text { wet tissue) }\end{array}$} \\
Tissue & $\begin{array}{c}\text { Copper- } \\
\text { Control }\end{array}$ & $\begin{array}{c}\text { Significance of } \\
\text { difference }\end{array}$ \\
Livert & $13.5 \pm 2.6$ & $109.4 \pm 21.2$ & $* * *$ \\
Kidney & $6.36 \pm 0.91$ & $11.64 \pm 0.91$ & $* *$ \\
Spleen & $1.35 \pm 0.16$ & $1.59 \pm 0.16$ & N.S. \\
Muscle & $0.88 \pm 0.08$ & $1.50 \pm 0.08$ & $* *$ \\
Fat & $0.66 \pm 0.27$ & $1.30 \pm 0.27$ & N.S.
\end{tabular}

Levels of significance of the effects of $\mathrm{CuSO}_{4} \cdot 5 \mathrm{H}_{2} \mathrm{O}$ compared with the control are shown as in Table $\mathrm{x}$.

N.S. = not significant.

$\dagger$ Logarithmic transformation was used (see p. 73).

Table 5. Exp. 2. Effect of diets supplemented with chlorotetracycline or copper sulphate on some visceral measurements of pigs

(Mean values for groups of six pigs)

\begin{tabular}{|c|c|c|c|c|c|}
\hline \multirow[b]{2}{*}{ Dietary supplement } & \multicolumn{2}{|c|}{ Gut } & \multirow[b]{2}{*}{$\begin{array}{l}\text { Liver } \\
\text { weight } \\
\text { (g) }\end{array}$} & \multirow[b]{2}{*}{$\begin{array}{l}\text { Kidneys } \\
\text { weight } \\
\text { (g) }\end{array}$} & \multirow[b]{2}{*}{$\begin{array}{c}\text { Spleen } \\
\text { weight } \\
\text { (g) }\end{array}$} \\
\hline & $\begin{array}{l}\text { Weight } \\
(\mathrm{g})\end{array}$ & $\begin{array}{c}\text { Length } \\
\text { (yd.) }\end{array}$ & & & \\
\hline None & I 648 & $22 \cdot 6$ & 1763 & 281 & 93 \\
\hline Aurofac 2 A (5 lb./2000 lb.) & 1457 & $22 \cdot 1$ & I 664 & 274 & $8 I *$ \\
\hline $\begin{array}{l}\mathrm{CuSO}_{4} \cdot 5 \mathrm{H}_{2} \mathrm{O}(0 \cdot \mathrm{r} \%) \\
\text { Standard error of the means }\end{array}$ & $\begin{array}{r}1534 \\
65\end{array}$ & $\begin{array}{r}22 \cdot 3 \\
0.6\end{array}$ & $\begin{array}{r}1702 \\
72\end{array}$ & $\begin{array}{r}298 \\
10\end{array}$ & $\begin{array}{l}100 \\
3.8\end{array}$ \\
\hline
\end{tabular}

Corrections have not been made for the slight variations in dead weight, since the regressions of none of the measurements on dead weight were significant.

* In the comparison of treatment and control means, this was the only difference that was significant $(P<0.05)$.

Visceral measurements. These measurements are given in Table 5 for the control diet, the diet supplemented with Aurofac $2 \mathrm{~A}$, and the diet supplemented with copper sulphate. Spleen weight was the only measurement to be significantly affected by the diets; it was decreased by the Aurofac supplement. The figures indicated a tendency for Aurofac $2 \mathrm{~A}$, and to a lesser extent copper sulphate, to reduce both gut and liver weight. 


\section{Experiment 3}

The mean rates of growth and daily food consumptions are shown graphically in Figs. I and 2. The daily intake of food by each of the pigs offered ad lib. the meal containing either $0.5 \%$ or $1.0 \%$ copper sulphate rapidly fell to a very low level, and the animals failed to gain weight over a period of from 3 to 5 weeks. Satisfactory growth and food intake were resumed by all pigs immediately the copper supplement was either removed from the diet or reduced to $0.1 \%$.

Apart from their refusal to eat the diets containing large amounts of copper and consequent failure to grow, none of the eight pigs concerned showed any obvious clinical signs of illness during the 7 weeks they were on experiment.

\section{DISCUSSION}

The results concerning the effect of copper and antibiotic supplements on growth rate, food conversion, food consumption and carcass quality extend those of Barber, Braude \& Mitchell (1955). The increase in rate of growth caused by dietary supplements of chlorotetracycline, oxytetracycline and copper sulphate was partly caused by increased food consumption, and with chlorotetracycline and copper sulphate there was also an improvement in the efficiency of food utilization which resulted in reduction of total food consumed from weaning to bacon weight. The effect of copper sulphate and antibiotic together has not yet been studied, but the results of Barber, Braude \& Mitchell (1955), who used a mineral mixture containing $4 \%$ copper sulphate, suggest that these effects are not additive. No carcass measurements were taken in this or earlier experiments involving copper supplements, so that further work is required before it will be possible to establish whether the supplements have any effect on carcass quality. The commercial grading can only serve as a preliminary means of appraisal.

The tendency of chlorotetracycline to reduce gut and liver weight confirms the findings of Braude et al. (1955) and of Taylor \& Harrington (1955); the latter workers' experiments also showed, as have the present experiments, a significant reduction in spleen weight. None of the visceral measurements was significantly affected by the copper-supplemented diet, but there is insufficient evidence to justify any comparison of the modes of action of copper and antibiotic supplements.

No indications of adverse effects have so far been observed in any pigs receiving a diet containing $0.1 \%$ copper sulphate, except possibly for a temporary digestive upset in some of the pigs in the earlier trial (Barber, Braude \& Mitchell, 1955). Even the animals offered the diets containing 0.5 or $\mathrm{r} \cdot 0 \%$ copper sulphate apparently suffered no permanent injury since they immediately resumed normal growth and food intake when the copper supplementation was reduced to the $0.1 \%$ level.

The distribution of copper in the body of pigs fed on an unsupplemented diet appears to be somewhat similar to the distribution in man (details of the distribution in man are given by Eggleton (1940) and Cartwright (1950)). The copper content of the livers of normal sheep and cattle is $12-16 \mathrm{mg} / \mathrm{kg}$ wet material (Ogilvie, 1954) and $20-80 \mathrm{mg} / \mathrm{kg}$ wet material (Monier-Williams, 1949), respectively; these values are of 

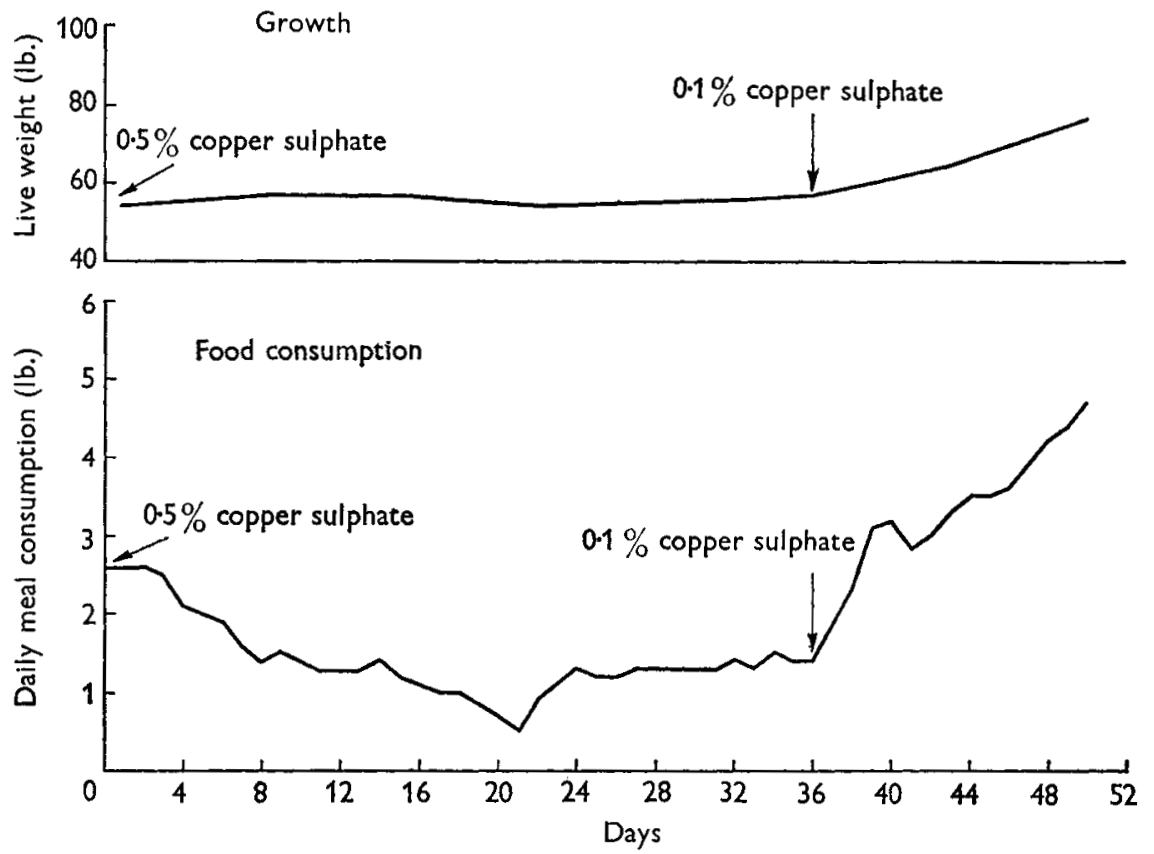

Fig. x. Effect on growth and food consumption of fattening pigs of dietary supplements of $0.5 \%$ and of $0.1 \%$ copper sulphate $\left(\mathrm{CuSO}_{4} .5 \mathrm{H}_{2} \mathrm{O}\right)$. (Mean values for four pigs.)

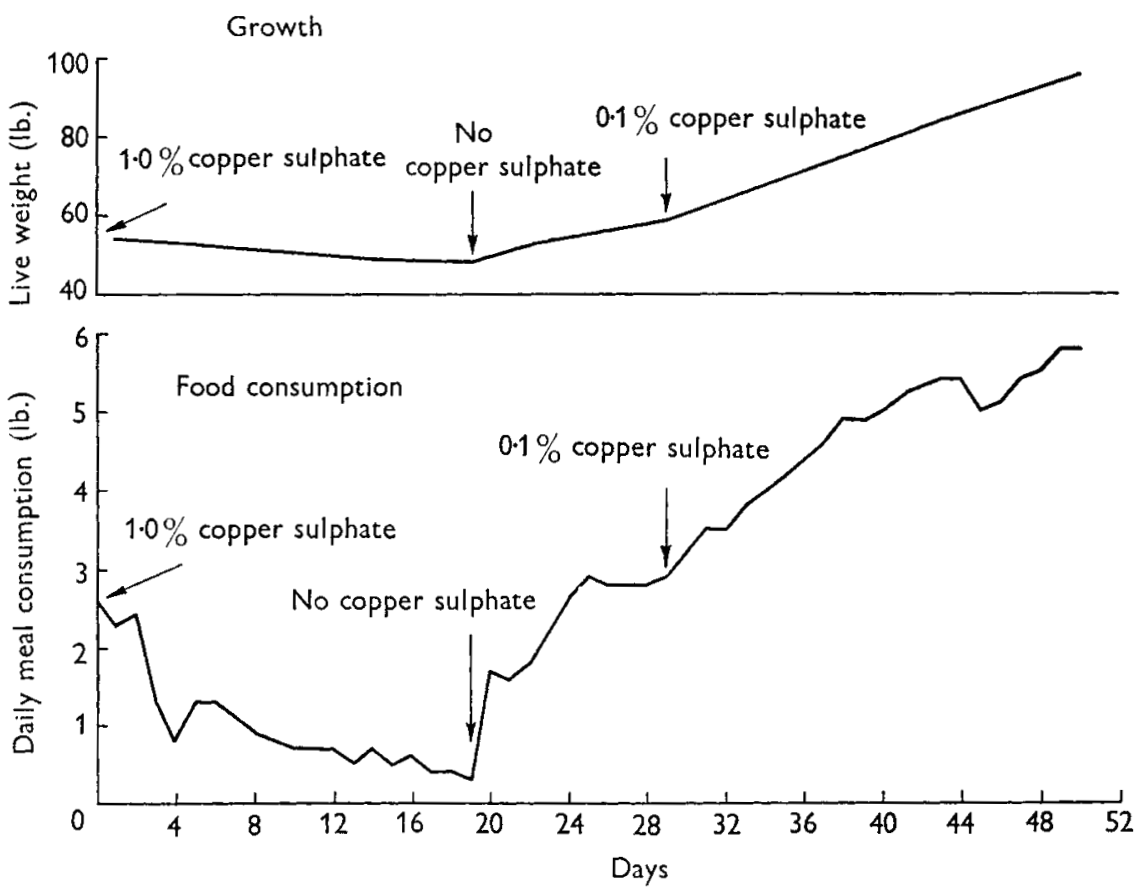

Fig. 2. Effect on growth and food consumption of fattening pigs of dietary supplements of $1.0 \%$ and of $0.1 \%$ copper sulphate $\left(\mathrm{CuSO}_{4} \cdot{ }_{5} \mathrm{H}_{2} \mathrm{O}\right)$. (Mean values for four pigs.) 
the same order as the figures of $13.5 \pm 2.6 \mathrm{mg} / \mathrm{kg}$ wet tissue for the pig as found in the present experiments. Cases of copper toxicity in sheep have been reported by Ogilvie (r954) and by Clegg (1956). The former considered that the danger level in the liver is $500-600 \mathrm{mg} / \mathrm{kg}$ and the latter found similar levels in his affected animals. Keeping the experiences with other farm animals in mind, we consider that further experiments are required with pigs, in order to ascertain whether high-copper feeding is harmless under all conditions of pig husbandry.

The question of whether pigs fed on diets supplemented with $0.1 \%$ copper sulphate are fit for human consumption may be considered by comparing copper levels in the liver and other tissues of such pigs with levels found in animals which are known to be suitable for human consumption. Monier-Williams (1949) gives a figure of $15^{\circ} \mathrm{mg} / \mathrm{kg}$ for the young calf and, since in the present results the treated pigs had only ro9. $4 \pm 21.2 \mathrm{mg} / \mathrm{kg}$ of copper in their livers and levels in other tissues were small, it would appear that pigs fed on diets containing $0.1 \%$ copper sulphate are suitable for human consumption.

\section{SUMMARY}

I. Seventy-eight individually fed Large White fattening pigs, $8 \frac{1}{2}-1 \mathrm{I}$ weeks old at the beginning of the two experiments carried out, were used to compare the effects of dietary supplements of either copper sulphate ( $0.1 \%$ ), oxytetracycline ( $\mathrm{I} \circ \mathrm{g} /$ ton), chlorotetracycline (about $20 \mathrm{~g} /$ ton as Aurofac $2 \mathrm{~A}$ ), a fermentation product, Vigofac (1o lb./ton) or a mixture of Vigofac and oxytetracycline on rate of gain, efficiency of food utilization and rate of food consumption.

2. Information was also obtained on the effect of dietary copper on the copper content of various tissues and organs, and of copper and chlorotetracycline supplements on the weight of various organs of the pig.

3. In a third experiment involving eight individually penned pigs, the effect of diets containing 0.5 and $\mathrm{I} \cdot 0 \%$ copper sulphate was investigated.

4. Copper sulphate, oxytetracycline and chlorotetracycline all significantly and similarly increased growth rate and rate of food consumption; the last also significantly improved the efficiency of food utilization. Vigofac had no significant effect on the performance of the animals. Combined results for both experiments showed that copper sulphate improved food conversion by $3.9 \%$, an effect that approached significance at the $5 \%$ level.

5. Of all carcasses, $76.6 \%$ were graded $A$ at the bacon factory. There was a reduction in triple-A carcasses from the copper-fed pigs but this reduction was not significant.

6. The liver copper of the copper-supplemented pigs varied from $25 \cdot 1$ up to $315^{.2} \mathrm{mg} / \mathrm{kg}$ wet material, the mean value of 109.4 being eight times that of the controls. Smaller increases in the other tissues and organs from the supplemented pigs were observed.

7. There was a tendency for chlorotetracycline to reduce gut and liver weight. Copper showed a similar, although less marked, effect on these organs. Chlorotetracycline also significantly reduced spleen weight. 
8. Food intake of pigs offered meal containing either 0.5 or $1 \cdot 0 \%$ copper sulphate rapidly fell to a very low level and the pigs failed to gain weight. All pigs resumed satisfactory growth and food intake immediately the copper supplement was reduced to $0.1 \%$, or omitted from the diet.

9. The results obtained are discussed in relation to the known toxic effects of feeding of very high amounts of copper to sheep and cattle.

\title{
REFERENCES
}

Andrus, S. (1955). Analyst, 80, $5 \mathrm{I} 4$.

Barber, R. S., Braude, R. \& Mitchell, K. G. (1955). Brit. J. Nutr. 9, 378.

Barber, R. S., Braude, R., Mitchell, K. G. \& Cassidy, J. (1955). Chem. E Ind. p. 601.

Barber, R. S., Braude, R., Mitchell, K. G., Rook, J. A. F. \& Rowell, J. G. (1956). Proc. Nutr. Soc. $\mathbf{r}_{5}$, ix.

Bowler, R. J., Braude, R., Campbell, R. C., Craddock-Turnbull, J. N., Fieldsend, H. F., Griffiths, E. K., Lucas, I. A. M., Mitchell, K. G., Nickalls, N. J. D. \& Taylor, J. H. (r955). Brit. F. Nutr. 9, 358.

Braude, R., Coates, M. E., Davies, M. K., Harrison, G. F. \& Mitchell, K. G. (1955). Brit. F. Nutr. 9, 363.

Cartwright, G. E. (1950). In A Symposium on Copper Metabolism. Baltimore: Johns Hopkins Press.

Clegg, F. G. (1956). Vet. Rec. 68, 332.

Eggleton, W. G. E. (r940). Biochem. F. 34, 99 I.

Monier-Williams, G. W. (1949). Trace Elements in Food. London: Chapman and Hall Ltd.

Ogilvie, D. D. (1954). Vet. Rec. 66, 279.

Taylor, J. H. \& Harrington, G. (1955). Nature, Lond., 175, 643.

\section{The specific dynamic action of food and the satiety mechanism}

\author{
By R. PASSMORE AND FIONA J. RITCHIE \\ Department of Physiology, University of Edinburgh
}

(Received 26 September 1956)

Food intake is controlled by two centres in the hypothalamus, a 'feeding centre' which promotes feeding and 'a satiety centre' which inhibits it. Several workers have contributed to the anatomical discovery of these centres (for review see Brobeck, 1956). The nature of the sensory stimuli to which these centres respond is, however, still uncertain. Brobeck (1948) has developed the hypothesis that increased heat production is an important signal to the satiety centre. In brief, he postulates that 'animals eat to keep warm and stop eating to prevent hyperthermia'. He is, however, careful to point out that changes in heat production may be only one of several stimuli to which the centres react. Indeed, Brobeck (1956) draws an analogy between the feeding centres and the respiratory centres, which are well known to be sensitive to several different types of stimulus. He (Brobeck, 1948; Strominger \& Brobeck, r953) has given two elegant demonstrations, using rats, which are entirely consistent with his 